\title{
Parathyroid hormone-related protein(1-34) in gestational fluids and release from human gestational tissues
}

\author{
W Farrugia ${ }^{1,2}$, P W M Ho ${ }^{3}$, G E Rice ${ }^{2}$, J M Moseley ${ }^{3}$, \\ M Permezel $^{2}$ and M E Wlodek ${ }^{1,2}$ \\ ${ }^{1}$ Department of Physiology, The University of Melbourne, Victoria 3010, Australia \\ ${ }^{2}$ Department of Obstetrics and Gynaecology, The University of Melbourne, Mercy Hospital for Women, East Melbourne, Victoria 3002, Australia \\ ${ }^{3}$ St Vincent's Institute of Medical Research, Fitzroy, Victoria 3065, Australia \\ (Requests for offprints should be addressed to M E Wlodek, Department of Physiology, The University of Melbourne, Victoria 3010, Australia; \\ Email: m.wlodek@physiology.unimelb.edu.au)
}

\begin{abstract}
Parathyroid hormone-related protein $(\mathrm{PTHrP})$ is present in fetal and gestational tissues, in which its proposed roles include stimulation of epithelial growth and differentiation, vasodilatation of the uteroplacental vasculature, relaxation of uterine muscle and stimulation of placental calcium transport. The aim of this study was to determine whether the release of PTHrP from gestational tissue explants was tissue specific. In addition, $\mathrm{PTHrP}$ concentrations were measured in maternal plasma, umbilical artery and vein plasma, and amniotic fluid from term, uncomplicated pregnancies before the onset of labour. PTHrP was detected in low concentrations in the mother, fetus and placental tissue. Amniotic fluid had ten times the PTHrP concentration compared with that in the maternal or fetal circulations. Using late pregnant human gestational tissues in an in vitro explant system, we found that amnion over placenta, choriodecidua, reflected amnion, and placenta released $\mathrm{PTHrP}$ into culture medium in progressively greater amounts over $24 \mathrm{~h}(P<0 \cdot 05)$. This release
\end{abstract}

was not associated with a loss of cell membrane integrity, as indicated by measurement of the intracellular enzyme, lactate dehydrogenase, in the incubation media. After $24 \mathrm{~h}$ incubation, the fetal membranes released significantly $(P<0.05)$ greater amounts of PTHrP than did the placenta (placenta $3 \cdot 7 \pm 0.5 \mathrm{pmol} \mathrm{PTHrP} / \mathrm{g}$ protein). Amnion over placenta released significantly more PTHrP (139.3 \pm $43.1 \mathrm{pmol} \mathrm{PTHrP} / \mathrm{g}$ protein) than did reflected amnion (29.0 $\pm 8 \cdot 3 \mathrm{pmol} \mathrm{PTHrP} / \mathrm{g}$ protein) $(P<0 \cdot 05)$. This study unequivocally demonstrated that human gestational tissues release PTHrP and it was concluded that the main contributors to PTHrP in amniotic fluid were the human fetal membranes, particularly amnion over placenta. Fetal membrane-derived and amniotic fluid PTHrP are proposed to have stimulatory effects on epithelial growth and differentiation in fetal lung, gut, skin and hair follicles and paracrine effects on placental vascular tone and calcium transport.

Journal of Endocrinology (2000) 165, 657-662

\section{Introduction}

Parathyroid hormone (PTH)-related protein (PTHrP) was initially described in tumours associated with humoral hypercalcaemia of malignancy (Albright 1941) and has since been localized to several non-malignant tissues, including fetal, reproductive and gestational tissues (Philbrick et al. 1996, Wysolmerski \& Stewart 1998). PTHrP, PTHrP mRNA and the PTH/PTHrP common receptor have been identified in fetal tissues, uterine smooth muscle, placenta and the fetal membranes, amnion and chorion (Moseley et al. 1991, Ferguson et al. 1992, Germain et al. 1992, Bowden et al. 1994, Philbrick et al. 1996, Curtis et al. 1997, 1998, Wysolmerski \& Stewart 1998). The tissue localization, temporal expression and in vitro effects of $\mathrm{PTHrP}$ in human gestational tissues suggest that this peptide acts locally in an autocrine/ paracrine manner. Evidence also suggests that PTHrP may act as a circulating hormone during fetal life (Daifotis et al. 1992, Seki et al. 1994, Papantoniou et al. 1996).

Both PTHrP and its PTH/PTHrP receptor are essential for fetal development. PTHrP-deficient mice, generated by partial PTHrP gene deletion and homologous recombination, die at birth because of severe skeletal dysplasia (Karaplis et al. 1994, Kovacs et al. 1996). Furthermore, mice with homologous deletion of the $\mathrm{PTH} / \mathrm{PTHrP}$ receptor gene are growth restricted and die at midgestation (Lanske et al. 1996). The proposed physiological roles for PTHrP in pregnancy include regulation of cellular growth and differentiation (Lee et al. 1995), vasodilatation of the uteroplacental vasculature (Mandsager et al. 1994, Macgill et al. 1997), relaxation of uterine muscle (Dalle 
et al. 1992, Paspaliaris et al. 1992, Williams et al. 1994) and stimulation of placental calcium transport (Care et al. 1990, Rodda et al. 1988).

High levels of expression of PTHrP mRNA and of protein are present in human amnion in comparison with placenta and choriodecidua (Ferguson et al. 1992, Germain et al. 1992, Curtis et al. 1997). PTHrP has been shown to be released from cytotrophoblast (Hellman et al. 1992) and amnion cell (Germain et al. 1992) cultures. Furthermore, we and others have demonstrated a significant upregulation of PTHrP mRNA and protein in human amnion (Ferguson et al. 1992, Curtis et al. 1997) and human amniotic fluid (Wlodek et al. 1995), but not PTH/PTHrP receptor mRNA (Curtis et al. 1998), at term compared with preterm. Interestingly, $\mathrm{PTHrP}$ gene expression and protein in amnion that overlies the fetal surface of the placenta (amnion over placenta) were significantly greater than in amnion that overlies choriodecidua (reflected amnion) (Curtis et al. 1997). The factors that regulate this differential expression of PTHrP and, indeed, its biological consequences are not known. Greater expression in amnion over placenta may, however, be important in the paracrine regulation of placental vascular tone and calcium transport. The aims of this study, therefore, were to compare the compartmental distribution of $\mathrm{PTHrP}$ in the human maternal-fetal unit at term and to investigate, in vitro, whether the release of $\mathrm{PTHrP}$ from human gestational tissue explants is tissue specific.

\section{Material and Methods}

\section{Reagents}

All reagents were obtained from Sigma Chemical Co. (St Louis, MO, USA) unless otherwise stated.

\section{Patients and samples}

This project was approved by the Mercy Hospital for Women Research and Ethics Committee and written, informed consent was obtained from participating patients. Samples were collected at term (37-42 weeks gestation) from women undergoing elective caesarean section, before the onset of labour from uncomplicated singleton pregnancies. We have previously demonstrated that PTHrP mRNA expression and protein content in human gestational tissues are not influenced by labour status or route of delivery (Curtis et al. 1997). Maternal and umbilical artery and vein blood were collected in lithium-heparin tubes (Sarstedt, Ingle Farm, South Australia, Australia) containing aprotonin (final concentration $0 \cdot 1 \mathrm{mg} / \mathrm{ml}$ ). Amniotic fluid samples were collected into sterilized plain polypropylene tubes containing aprotonin (Sarstedt). Plasma and amniotic fluids were separated by centrifugation using a Beckman GS-15 centrifuge (Beckman Instruments, Palo
Alto, CA, USA) at 3000 r.p.m. for $10 \mathrm{~min}$, aliquoted and stored at $-80{ }^{\circ} \mathrm{C}$ until required for assay for $\mathrm{PTHrP}$ immunoreactivity. Placentae and attached fetal membranes were obtained from women undergoing elective caesarean section, before the onset of labour and tissue processing was commenced within $15 \mathrm{~min}$ of delivery of the placenta.

\section{Explants}

Placental tissue was obtained from a cotyledon. Avascular amnion readily peeled off the underlying chorion. Amnion over placenta and reflected amnion were obtained by blunt dissection. All tissues were placed in ice-cold RPMI (RPMI 1640, Phenol Red Free, Gibco Laboratories, Grand Island, NY, USA). The fetal membranes were cut into $1 \mathrm{~cm}^{3}$ sections and the placental tissue was teased apart using blunt dissection and placed in RPMI at $37^{\circ} \mathrm{C}$ in a humidified atmosphere of Carbogen $\left(95 \% \mathrm{O}_{2}\right.$ and $5 \%$ $\mathrm{CO}_{2}$ ) for $1 \mathrm{~h}$. Explants were then blotted dry on sterile filter paper and transferred to 12-well tissue culture plates (Flow Laboratories, McClean, VA, Canada; 150-250 mg wet weight/well). The explants were incubated in $2 \mathrm{ml}$ RPMI containing penicillin $\mathrm{G}(100 \mathrm{U} / \mathrm{ml})$ and streptomycin $(100 \mu \mathrm{g} / \mathrm{ml})$ for $0,1,3,6$ and $24 \mathrm{~h}$ in duplicate. At the end of incubations gestational tissues and media were frozen and stored at $-20{ }^{\circ} \mathrm{C}$ until required for processing. Samples of frozen gestational tissues (150-250 mg) were homogenized using a metal blade homogenizer (Ultraturrax, T8 dispersing tool; Jenke and Kunkle GMBH and Co., Staufen, Germany) for 20 s at 24000 r.p.m. in $1 \mathrm{M}$ acetic acid $(1: 5 \mathrm{w} / \mathrm{v})$. The homogenate was centrifuged at 3000 r.p.m. for $10 \mathrm{~min}$ at $4{ }^{\circ} \mathrm{C}$. The supernatant was collected and stored at $-20^{\circ} \mathrm{C}$ until required for assay.

\section{PTHrP, lactate dehydrogenase and protein assays}

PTHrP in plasma, amniotic fluid and tissues was quantified using a sensitive (2 pmol/l detection limit) and specific N-terminal PTHrP radioimmunoassay as previously described (Grill et al. 1991). This radioimmunoassay uses a polyclonal goat antiserum against $\mathrm{PTHrP}(1-$ 40), against synthetic $\mathrm{PTHrP}(1-40)$ and $\mathrm{PTHrP}(1-84)$ as standard. There was no cross-reactivity with parathyroid hormone. The intra- and interassay coefficients of variation were 4.8 and $13.6 \%$ respectively.

To assess the effects of experimental treatment on cell membrane integrity, release of the intracellular enzyme lactate dehydrogenase (LDH) into incubation medium was determined as previously described (Farrugia et al. 1999). The protein content of gestational tissues, homogenates and supernatants was determined using the Pierce BCA Protein Assay Kit (Pierce, Rockford, IL, USA) in which protein, via reduction of copper ion, forms a cuprous ion that chelates bicinchoninic acid (BCA), producing a purple-coloured reaction. Bovine serum albumin was used 
Table 1 PTHrP concentrations in maternal and umbilical plasma and amniotic fluid from normal term pregnancies. Data are presented as mean \pm S.E.M. (number of patients)

\begin{tabular}{lc} 
& PTHrP $(\mathrm{pmol} / \mathrm{l})$ \\
\cline { 2 - 2 } Compartment & \\
Maternal plasma & $2 \cdot 7 \pm 0 \cdot 4(10)$ \\
Arterial cord plasma & $6 \cdot 6 \pm 2 \cdot 0(10)$ \\
Venous cord plasma & $3 \cdot 2 \pm 0 \cdot 6(12)$ \\
Amniotic fluid & $41 \cdot 8 \pm 3 \cdot 8(16)^{\star}$
\end{tabular}

*Amniotic fluid PTHrP concentrations significantly greater than in any other compartment $(P<0 \cdot 0001)$.

as a reference standard. Twenty-five microlitres homogenate were transferred into a microfuge tube and $25 \mu \mathrm{l}$ $10 \mathrm{M} \mathrm{NaOH}$ added. Samples were boiled for $10 \mathrm{~min}$, cooled and $50 \mu \mathrm{l} 10 \mathrm{M} \mathrm{HCl}$ added to neutralize the solution. The intra- and interassay coefficients of variation were $5 \cdot 0$ and $5 \cdot 5 \%$ respectively.

\section{Statistics}

Statistical analyses were performed using a commercially available statistical analysis package (Statgraphics, STSC, Rockville, MD, USA). Homogeneity of variance was tested using Bartlett's test (Bartlett 1937); the variance was determined to be non-homogenous and all data were logarithmically transformed before further analysis. Data was analysed by either Student's $t$-test (for comparison between two groups) or multifactorial analysis of variance (ANOVA, for comparisons between three or more groups) followed by Fisher's least significant difference test. Statistical significance was taken as $P<0 \cdot 05$. Data are expressed as mean \pm standard error of the mean (s.E.M.).

\section{Results}

\section{Circulating and amniotic fluid PTHrP}

$\mathrm{PTHrP}$ concentrations in term maternal plasma averaged $2 \cdot 7 \pm 0.4 \mathrm{pmol} / 1$ (Table 1$)$. There were no significant differences between PTHrP concentrations in arterial cord plasma, venous cord plasma or maternal plasma (Table 1). However, amniotic fluid PTHrP concentrations (41.8 \pm $3.8 \mathrm{pmol} / \mathrm{l})$ were at least tenfold greater than maternal or umbilical plasma values $(P<0 \cdot 0001$; Table 1$)$.

\section{PTHrP release from gestational tissue explants}

$\mathrm{PTHrP}$ release from human gestational tissues increased significantly and progressively over $6 \mathrm{~h}$ in all tissues $(P<0 \cdot 05$; Fig. 1) and was increased further at $24 \mathrm{~h}$ in reflected amnion, amnion over placenta and choriodecidua $(P<0 \cdot 05$; Fig. 1). After $24 \mathrm{~h}$ of incubation, fetal membrane (amnion over placenta, choriodecidua and reflected
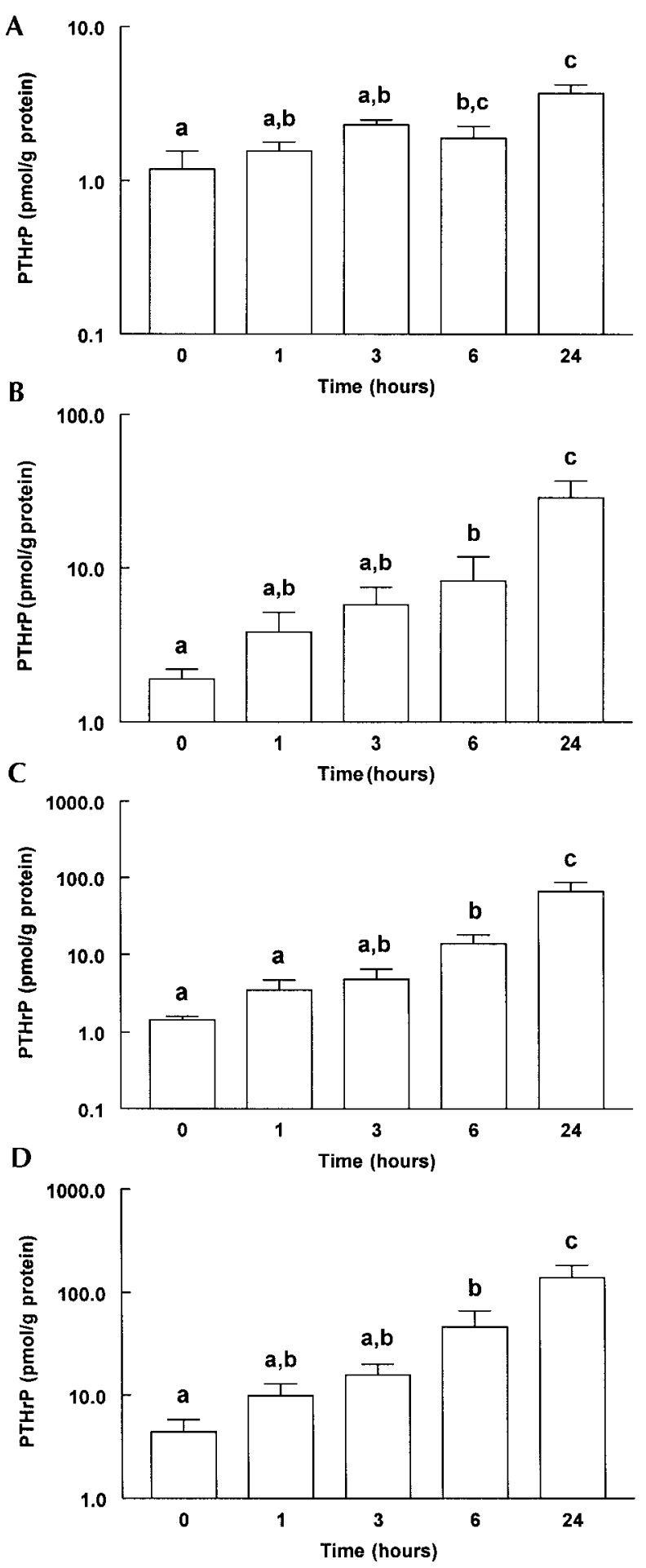

Figure 1 Time course of release of PTHrP from explants of placenta (A), reflected amnion (B), choriodecidua (C) and amnion over placenta (D) incubated at $37^{\circ} \mathrm{C}$ in RPMI in the presence of Carbogen. Data are expressed as mean \pm S.E.M., $n=4$. Values that share a common letter are not significantly different from one another $(P<0 \cdot 05$, ANOVA). 
Table 2 PTHrP and LDH release from human gestational tissue explants after $24 \mathrm{~h}$ explant culture from various gestational tissue compartments, from four normal term pregnancies. Data are presented as mean \pm S.E.M.

\begin{tabular}{|c|c|c|}
\hline & $\begin{array}{l}\text { PTHrP release } \\
(\mathrm{pmol} / \mathrm{g} \text { protein }) \\
(n=4)\end{array}$ & $\begin{array}{l}\text { LDH release }(\%) \\
(n=4)\end{array}$ \\
\hline \multicolumn{3}{|l|}{ Tissue } \\
\hline Placenta & $3 \cdot 7 \pm 0 \cdot 5^{a}$ & $3 \cdot 1 \pm 1 \cdot 7$ \\
\hline Reflected amnion & $29 \cdot 0 \pm 8 \cdot 3^{b}$ & $3 \cdot 3 \pm 1 \cdot 1$ \\
\hline Choriodecidua & $65 \cdot 7 \pm 20 \cdot 8^{\mathrm{bc}}$ & $3 \cdot 4 \pm 1 \cdot 5$ \\
\hline Amnion over placenta & $139 \cdot 3 \pm 43 \cdot 1^{\mathrm{c}}$ & $4 \cdot 7 \pm 1 \cdot 8$ \\
\hline
\end{tabular}

Data values that share a common letter are not significantly different from one another $(P<0 \cdot 05$, ANOVA). Amnion over placenta, reflected amnion and choriodecidua released significantly more PTHrP than placenta $(P<0.05)$; amnion over placenta released significantly more PTHrP than did reflected amnion explants $(P<0 \cdot 05)$.

amnion) PTHrP release was at least tenfold greater than placental PTHrP release $(P<0 \cdot 05$; Fig. 1 , Table 2$)$. PTHrP release from amnion over placenta $(139 \cdot 3 \pm 43 \cdot 1 \mathrm{pmol} / \mathrm{l})$ was not significantly different from that of choriodecidua $(65 \cdot 7 \pm 20 \cdot 8 \mathrm{pmol} / \mathrm{l})$, but was significantly greater than that of reflected amnion $(29 \cdot 0 \pm 8.3 \mathrm{pmol} / 1 ; \quad P<0 \cdot 05$; Table 2). The release of PTHrP was not associated with a concomitant release of the intracellular enzyme and marker of cell membrane integrity, LDH (Table 2). LDH recovery in the incubation medium across all the gestational tissue explants studied, after $24 \mathrm{~h}$ of incubation, showed no significant differences and on average was less than $4 \cdot 0 \%$ of total tissue content (Table 2).

\section{Discussion}

Low concentrations of N-terminal PTHrP were found in the circulation of the mother and the fetus and in placental tissue. Although the literature reports that umbilical cord PTHrP concentrations are greater than maternal values and that the placenta is the source of circulating fetal PTHrP (Daifotis et al. 1992, Seki et al. 1994, Papantoniou et al. 1996), data obtained in this study do not support this proposal. The low levels of PTHrP released from the placenta support our finding of no umbilical venous to arterial gradient and suggest that the placenta is not a major source of circulating PTHrP in the fetus. The findings of the present report are consistent with those of Papantoniou et al. (1996), who reported low but detectable levels of PTHrP(1-86) that were not different from maternal values.

Amniotic fluid PTHrP concentrations from term human pregnancy were found to be approximately $40 \mathrm{pmol} / 1$, which is consistent with other reported values (Dvir et al. 1995, Wlodek et al. 1995). As there is no detectable PTHrP in fetal urine (Ferguson et al. 1992, Wlodek et al. 1995), it has been suggested that the PTHrP found in amniotic fluid is derived from the amnion. It has also been shown that primary cultures of human amniotic cells secrete PTHrP (Germain et al. 1992). We therefore used an in vitro explant system to elucidate the gestational tissue source of PTHrP in amniotic fluid and whether there is differential release from human gestational tissues.

Gestational tissue explant systems have been shown to synthesize and release vitamin D3, prorenin, cytokines, prostaglandins and phospholipase A2 (Rubin et al. 1993, Downing et al. 1996, Laham et al. 1996, Farrugia et al. 1997, Simpson et al. 1999). This study, for the first time, unequivocally demonstrated the release of PTHrP from human gestational tissues. Furthermore, the gestational tissue that released the most PTHrP into the culture medium was the amnion over placenta. Thus the present study confirms that PTHrP is preferentially produced and released from the amnion over placenta. The release of PTHrP observed in this study was not associated with the loss of cell membrane integrity, as indicated by the measurement of the intracellular enzyme LDH. We and others have previously reported that human gestational tissue expression of PTHrP and its mRNA is tissue specific (Ferguson et al. 1992, Germain et al. 1992, Curtis et al. 1997). Furthermore, PTHrP and its mRNA were more abundant in the amnion over placenta than in the reflected amnion, with low values in the placenta (Curtis et al. 1997). The concentrations of PTHrP released from human amnion and present in amniotic fluid are significantly greater than those found in the fetal or maternal circulation and thus amnion-derived and amniotic fluid PTHrP are likely to have physiological roles during human pregnancy. Paracrine influences of the placenta and choriodecidua may account for the differential expression of PTHrP in amnion over placenta and reflected amnion. Several placental and decidual hormones, cytokines and growth factors have been demonstrated to increase gestational tissue expression and release of PTHrP mRNA (Thiede et al. 1991, Casey et al. 1992, Germain et al. 1992, Paspaliaris et al. 1992, Williams et al. 1994, Dvir et al. 1995). The high concentrations of PTHrP released from choriodecidua, relative to placenta and reflected amnion, may be the result of contributions from the decidual cells of the maternal endometrium (Thiede et al. 1991, Paspaliaris et al. 1992, Williams et al. 1994).

The specific roles of fetal membrane-derived and amniotic fluid PTHrP have yet to be elucidated, but are recognized as important paracrine components of the fetal-maternal communication system. Amnion-derived PTHrP may be important for amnion cell growth and differentiation or may have paracrine functions in the placenta and in the fetus. PTHrP derived from amnion over placenta may act in a paracrine manner to stimulate placental calcium transport (Rodda et al. 1988, Care et al. 1990, Fraher et al. 1992, Kovacs et al. 1996) and fetalplacental vasodilatation (Mandsager et al. 1994, Macgill et al. 1997). Fetal breathing and swallowing would allow 
amniotic fluid PTHrP to reach the fetal lung and gastrointestinal epithelia respectively. Also, the fetal skin, hair follicles and amnion epithelium are continually bathed in amniotic fluid. Thus amniotic fluid PTHrP could stimulate epithelial growth and differentiation (Kaiser et al. 1994) and may assist in the maturation of these tissues and organs.

During fetal lung development, PTHrP is predominantly expressed in bronchial epithelia and alveolar type II cells, whereas its receptor is found in the subepithelial mesenchyme (Hastings et al. 1994, Rubin et al. 1994). PTHrP-deficient mice were found to have lung hypoplasia, arrested canalicular development and impaired epithelial cytodifferentiation (Rubin et al. 1997). PTHrP and its receptor have been shown to be important in the stimulation of lung surfactant phospholipid synthesis (Rubin et al. 1994). Recently, PTHrP has been found in washings from the intubated tracheae of newborn infants and concentrations increased from preterm to term gestation (Speziale et al. 1998). Tracheal fluid PTHrP may be derived from the lung itself or from amniotic fluid and may have significant roles in fetal lung development near term.

Rescued PTHrP-knockout mice display a number of skin-related changes, including thinned epidermis, hyperkeratosis, hypoplastic sebaceous glands and a fibrotic dermis (Foley et al. 1998). In contrast, transgenic mice that overexpress PTHrP display thickened ventral epidermis, acanthosis, papillomatosis and hyperplastic sebaceous glands and cellular dermis (Wysolmerski et al. 1994). Furthermore, in the PTHrP-overexpressed transgenic mouse model there was failure to initiate follicle development (Wysolmerski et al. 1994). These studies demonstrate the important role that amniotic fluid and fetal PTHrP play in the development of hair and skin.

Amniotic fluid PTHrP is in much greater concentrations than that found in either the maternal or fetal circulation. By utilizing an in vitro explant system, we have demonstrated that PTHrP is predominantly released from human fetal membranes, particularly the amnion over placenta. Fetal membrane-derived and amniotic fluid PTHrP thus may have important roles in fetal organ growth and development and placental function. This study provides a model whereby biochemical mechanisms that regulate PTHrP release under normal conditions and in pathological conditions in which fetal growth and placental function are compromised, can be investigated.

\section{Acknowledgements}

This work was supported by the Medical Research Foundation for Women and Babies and a Principal Research Fellowship (GER) from the National Health and Medical Research Council of Australia. The authors gratefully acknowledge the assistance of clinical Research Midwives Lyn Tuttle and Jane Goldsmith and the
Obstetric and Midwifery staff of the Mercy Hospital for Women for their cooperation.

\section{References}

Albright F 1941 Case records of the Massachusetts General Hospital: case 27461. New England Journal of Medicine 225 789-791.

Bartlett MS 1937 Some examples of statistical methods of research in agriculture and applied biology. Journal of the Royal Statistics Society (Suppl) 4 137-170.

Bowden SJ, Emly JF, Hughes SV, Powell G, Ahmed A, Whittle MJ, Ratcliffe JG \& Ratcliffe WA 1994 Parathyroid hormone-related protein in human term placenta and membranes. Journal of Endocrinology 142 217-224.

Care AD, Abbas SK, Pickard DW, Barri M, Drinkhill M, Findlay JBC, White IR \& Caple IW 1990 Stimulation of ovine placental transport of calcium and magnesium by mid-molecule fragments of human parathyroid hormone-related protein. Experimental Physiology 75 605-608.

Casey ML, Mibe M, Erk A \& MacDonald PC 1992 Transforming growth factor- $\beta 1$ stimulation of parathyroid hormone-related protein expression in human uterine cells in culture: mRNA levels and protein secretion. Journal of Clinical Endocrinology and Metabolism 74 950-952.

Curtis NE, Ho PWM, King RG, Farrugia W, Moses EK, Gillespie MT, Moseley JM, Rice GE \& Wlodek ME 1997 The expression of parathyroid hormone related protein mRNA and immunoreactive protein in human amnion and choriodecidua is increased at term compared with preterm gestation. Journal of Endocrinology 154 103-112.

Curtis NE, Thomas RJ, Gillespie MT, King RG, Rice GE \& Wlodek ME 1998 Parathyroid hormone-related protein (PTHrP) mRNA splicing and parathyroid hormone/PTHrP receptor mRNA expression in human placenta and fetal membranes. Journal of Molecular Endocrinology $21225-234$.

Daifotis AG, Weir EC, Dreyer BE \& Broadus AE 1992 Stretch-induced parathyroid hormone-related peptide gene expression in the rat uterus. Journal of Biological Chemistry 267 23445-23458.

Dalle M, Dauprat-Dalle P \& Barlet J-P 1992 Parathyroid hormone-related peptide inhibits oxytocin-induced rat uterine contractions in vitro. Archives Internationales de Physiologie, de Biochimie et de Biophysique 101 251-254.

Downing GJ, Maulik D \& Poisner AM 1996 Human chorionic gonadotropin stimulates placental prorenin secretion - evidence for autocrine-paracrine regulation. Journal of Clinical Endocrinology and Metabolism 81 1027-1030.

Dvir R, Golander A, Jaccard N, Yedwab G, Otremski I, Spirer Z \& Weisman Y 1995 Amniotic fluid and plasma levels of parathyroid hormone-related protein and hormonal modulation of its secretion by amniotic fluid cells. European Journal of Endocrinology 133 277-282.

Farrugia W, Rice GE, Wong MH, Scott KF \& Brennecke SP 1997 Release of type II phospholipase A2 immunoreactivity and phospholipase A2 enzymatic activity from human placenta. Journal of Endocrinology 153 151-157.

Farrugia W, Nicholls L \& Rice GE 1999 Effect of bacterial endotoxin on the in vitro release of type II phospholipase-A2 and prostaglandin E2 from human placenta. Journal of Endocrinology 160 291-296.

Ferguson JE, Gorman JV, Bruns DE, Weir EC, Burtis WJ, Martin TJ \& Bruns ME 1992 Abundant expression of parathyroid hormonerelated protein in human amnion and its association with labor. PNAS 89 8384-8388.

Foley J, Longely BJ, Wysolmerski JJ, Dreyer BE, Broadus AE \& Philbrick WM 1998 PTHrP regulates epidermal differentiation in adult mice. Journal of Investigative Dermatology 111 1122-1128. 
Fraher LJ, Hodsman AB, Jonas K, Saunders D, Rose CI, Henderson JE, Hendy GN \& Goltzman D 1992 A comparison of the in vivo biochemical responses to exogenous parathyroid hormone-(1-34) (PTH-(1-34)) and PTH-related peptide-(1-34) in man. Journal of Clinical Endocrinology and Metabolism 75 417-423.

Germain AM, Attaroglu H, MacDonald PC \& Casey ML 1992 Parathyroid hormone-related protein mRNA in avascular human amnion. Journal of Clinical Endocrinology and Metabolism $\mathbf{7 5}$ $1173-1175$.

Grill V, Ho P, Body JJ, Johanson N, Lee SC, Kukreja SC, Moseley JM \& Martin TJ 1991 Parathyroid hormone-related protein: elevated levels in both humoral hypercalcemia of malignancy and hypercalcemia complicating metastatic breast cancer. Journal of Clinical Endocrinology and Metabolism 73 1309-1315.

Hastings RH, Duong H, Burton DW \& Deftos LJ 1994 Alveolar epithelial cells express and secrete parathyroid hormone-related protein. American Journal of Respiratory Cell and Molecular Biology 11 701-706.

Hellman P, Ridefelt P, Juhlin C, Akerstrom G, Rastad J \& Gylfe E 1992 Parathyroid-like regulation of parathyroid hormone-related protein release and cytoplasmic calcium in cytotrophoblast cells of human placenta. Archives of Biochemistry and Biophysics 293 174-180.

Kaiser SM, Sebag M, Rhim JS, Kremer R \& Goltzman D 1994 Antisense-mediated inhibition of parathyroid hormone-related peptide production in a keratinocyte cell line impedes differentiation. Molecular Endocrinology 8 139-147.

Karaplis AC, Luz A, Glowacki J, Bronson RT, Tybulewicz LJ, Kronenberg HM \& Mulligan RC 1994 Lethal skeletal dysplasia from targeted disruption of the parathyroid hormone-related peptide gene. Genes and Development 8 277-289.

Kovacs CS, Lanske B, Hunzelman JL, Guo J, Karaplis AC \& Kronenberg HM 1996 Parathyroid hormone-related peptide $(\mathrm{PTHr})$ regulates fetal-placental calcium transport through a receptor distinct from the PTH/PTHrP receptor. PNAS $\mathbf{9 3}$ 15233-15238.

Laham N, Brennecke SP, Bendtzen K \& Rice GE 1996 Labourassociated increase in interleukin-1-alpha release in vitro by human gestational tissues. Journal of Endocrinology 150 515-522.

Lanske B, Karaplis AC, Lee K, Luz A, Vortkamp A, Pirro A, Karperien M, Defize L, Ho C, Mulligan RC, Abousamra AB, Juppner H, Segre GV \& Kronenberg HM 1996 PTH/PTHrP receptor in early development and Indian Hedgehog-regulated bone growth. Science 273 663-666.

Lee K, Deeds JD \& Segre GV 1995 Expression of parathyroid hormone-related peptide and its receptor messenger ribonucleic acids during fetal development of rats. Endocrinology 136 453-463.

Macgill K, Wlodek M, Moseley JM, Martin TJ, Brennecke SP \& Rice GE 1997 Vascular effects of PTHrP(1-34) in the human fetal-placental circulation. Placenta 18 587-592.

Mandsager NT, Brewer AS \& Myatt L 1994 Vasodilator effects of parathyroid hormone, parathyroid hormone-related protein, and calcitonin gene-related peptide in the human fetal-placental circulation. Journal of the Society for Gynecologic Investigation 1 19-24.

Moseley JM, Hayman JA, Danks JA, Alcorn D, Grill V, Southby J \& Horton MA 1991 Immunohistochemical detection of parathyroid hormone-related protein in human fetal epithelia. Journal of Clinical Endocrinology and Metabolism 73 478-484.

Papantoniou NE, Papapetrou PD, Antsaklis AJ, Kontoleon PE, Mesogitis SA \& Aravantinos D 1996 Circulating levels of immunoreactive parathyroid hormone-related protein and intact parathyroid hormone in human fetuses and newborns. European Journal of Endocrinology 134 437-442.

Paspaliaris V, Vargas SJ, Gillespie MT, Williams ED, Danks JA, Moseley JM, Story ME, Pennefather JN, Leaver DD \& Martin TJ
1992 Oestrogen enhancement of the myometrial response to exogenous parathyroid hormone-related protein (PTHrP), and tissue localization of endogenous PTHrP and its mRNA in the virgin rat uterus. Journal of Endocrinology 134 415-425.

Philbrick WM, Wysolmerski JJ, Galbraith S, Holt E, Orloff JJ, Yang KH, Vasavada RC, Weir EC, Broadus AE \& Stewart AF 1996 Defining the roles of the parathyroid hormone-related protein in normal physiology. Physiological Reviews 76 127-173.

Rodda CP, Kubota M, Heath JA, Ebeling PR, Moseley JM, Care AD, Caple IW \& Martin TJ 1988 Evidence for a novel parathyroid hormone-related protein in fetal lamb parathyroid glands and sheep placenta: comparisons with a similar protein implicated in humoral hypercalcaemia of malignancy. Journal of Endocrinology 117 261-271.

Rubin LP, Yeung BPLM \& Reddy GS 1993 Evidence for human placental synthesis of 24,25-dihydroxyvitamin-D3 and 23,25dihydroxyvitamin D3. Pediatric Research 34 98-104.

Rubin LP, Kifor O, Hua J, Brown EM \& Torday JS 1994 Parathyroid hormone $(\mathrm{PTH})$ and PTH-related protein stimulate surfactant phopholipid synthesis in rat fetal lung, apparently by a mesenchymal-epithelial mechanism. Biochemical and Biophysical Research Communications 1223 91-100.

Rubin LP, Kovacs CA, Tsai SW, Pinar H, Torday J \& Kronenberg HM 1997 The parathyroid hormone-related protein (PTHrP) knockout mouse shows delayed lung development. Pediatric Research $41266 \mathrm{~A}$

Seki K, Wada S, Nagata N \& Nagata I 1994 Parathyroid hormonerelated protein during pregnancy and the perinatal period. Gynecologic and Obstetric Investigation 37 83-86.

Simpson KL, Keelan JA \& Mitchell MD 1999 Labour-associated changes in the regulation of production of immunomodulators in human amnion by glucocorticoids, bacterial lipopolysaccharide and pro-inflammatory cytokines. Journal of Reproduction and Fertility 116 321-327.

Speziale MV, Mannino FL, Astings RH \& Deftos L 1998 Parathyroid hormone-related protein in tracheal aspirates of newborn infants. Pediatric Research 43 660-665.

Thiede MA, Harm SC, Hasson DM \& Gardner RM 1991 In vivo regulation of parathyroid hormone-related peptide messenger ribonucleic acid in the rat uterus by 17 -estradiol. Endocrinology 128 2317-2323.

Williams ED, Leaver DD, Danks JA, Moseley JM \& Martin TJ 1994 Effect of parathyroid hormone-related protein $(\mathrm{PTHrP})$ on the contractility of the myometrium and the localization of PTHrP in the uterus of pregnant rats. Journal of Reproduction and Fertility 102 209-214.

Wlodek ME, Ho PWM, Rice GE, Moseley JM, Martin TJ \& Brennecke SP 1995 Parathyroid hormone-related protein (PTHrP) concentrations in human amniotic fluid during gestation and at the time of labour. Reproduction Fertility and Development 7 1509-1513.

Wysolmerski JJ \& Stewart AF 1998 The physiology of parathyroid hormone-related protein: an emerging role as a developmental factor. Annual Review of Physiology 60 431-460.

Wysolmerski JJ, Broadus AE, Zhou J, Fuchs E, Milstone LM \& Philbrick WM 1994 Overexpression of parathyroid hormone-related protein in the skin of transgenic mice interferes with hair follicle development. PNAS 91 1133-1137.

Received 25 November 1999

Accepted 31 January 2000 